\title{
Curcuma longa ingestion protects in vitro hepatocyte membrane peroxidation
}

\author{
Sonia Torquato Paolinelli', Rashmeet Reen², Tasso Moraes-Santos* \\ ${ }^{1}$ Departamento de Alimentos, Faculdade de Farmácia, Universidade Federal de Minas Gerais \\ ${ }^{2}$ Ohio State University, College of Medicine and Public Health
}

*Correspondence:

T. Moraes-Santos

Departamento de Alimentos

Faculdade de Farmácia

Universidade Federal de Minas Gerais

Av. Antônio Carlos, 6627

31270-901 - Belo Horizonte, MG - Brasil

E-mail: tmoraes@ufmg.br
The goal of the present study was to evaluate the effect of turmeric ingestion on lipid peroxidation and GSH content, promoted by in vitro acetaminophen, on hepatocytes primary culture from wellnourished and malnourished rats. Four groups of Holtzman male rats were used: 1) WNG, well-nourished, fed lab chow diet ad libitum; 2) $M N G$, malnourished, fed $60 \%$ of the diet consumed by $W N G$; 3) $W N G+T$ fed the same diet of $W N G$, but containing $1 \%$ of turmeric; 4) $M N G+T$ fed $60 \%$ of the diet consumed by $W N G+T$. The animals were sacrificed at 90 days of age, the livers excised and hepatocytes primary cultures were prepared. Half of the plates of hepatocytes culture were treated with acetaminophen. Doseresponse curve showed that $6 \mathrm{mM}$ acetaminophen increased peroxidation around $54 \%$ and decreased GSH content around $63 \%$. The model of malnutrition used, by restricting food ingestion (40\%), decreased body weight in 33\% and peroxidation index around $42 \%$ and increased GSH content around 43\%. Turmeric ingestion decreased hepatocyte peroxidation in both well-nourished (42\%) and malnourished rats (33\%) and was able to avoid the acetaminophen pro-oxidant effect in both well-nourished and malnourished animals. Turmeric ingestion played a beneficial role to the organism and, therefore, can be considered a functional food.
Uniterms

- Turmeric

- Acetaminophen

- Food restriction

- Lipid peroxidation

- Hepatocytes primary culture

\section{INTRODUCTION}

Turmeric dry rhizome has been claimed to have antiinflammatory, antioxidant (Donatus et al., 1990; Masuda, Jitoe, 1994) and anticarcinogenic properties (Iqbal et al., 2003), as well as regulating bile functions (Ramprasad, Sirsi, 1956). It also exhibits anti-hepatotoxic activity (Kiso et al., 1983 ) and could be used as a functional food, because it protects cells against damage. Furthermore, it has been used for a long time as a coloring agent and spice. Therefore it can be easily added to food, protecting against cellular damage (Ramsewak et al., 2000; Joe et al., 2004). Turmeric contains several curcuminoid pigments: curcumin, demetoxicurcumin and bisdemetoxicurcumin (Kawamori et al., 1999). Curcumin acts against lipid peroxidation, functioning, therefore, as an antioxidant in cells (Masuda, Jitoe, 1994). 
Acetaminophen (4' hydroxyacetanilide) is a widely used analgesic and antipyretic drug that has been used as a model to study toxic mechanisms, evaluation of the efficacy of other therapeutic agents and preventive compounds in hepatotoxicity (Vermeulen et al., 1992). However, part of the drug, mainly when used at a high dose, is metabolized by monooxigenases, producing a toxic metabolite known as $N$ acetyl- $p$-benzoquinone imine (NAPQI) involved in severe hepatic necrosis for both man and experimental animal (Prescott, 1983; Bessems, Vermeulen, 2001). This electrophylic metabolite conjugates with reduced glutathione (GSH) to form 3-glutathionyl acetaminophen derivatives, decreasing GSH content in the cell and subsequently causing hepatic damage (Vermeulen et al., 1992).

Lipid peroxidation in tissues is a degenerative process involving free radicals and polyunsaturated fatty acids (PUFAs), mainly arachidonic acid. The peroxidative effect on PUFAs leads to hepatic pathogenesis, similar to that induced by acetaminophen (Poli et al., 1987). Several methods can be used to evaluate lipid peroxidation and the reaction with thiobarbituric acid (TBA) is widely used (Plaa, Witschi, 1976). Malonaldehyde (MDA) is one of the final secondary products of the oxidized polyunsaturated fatty acids degradation that can be colorimetrically evaluated in the extracellular medium. The similar color developed by thiobarbituric acid reactive substances (TBARS) is usually used as an index of lipid peroxidation, in spite of the lack of specificity. The rat primary culture of hepatocytes seems to be a useful model for lipid peroxidation investigation, since it allows a wide evaluation of different toxicological studies (Sergent et al., 1993).

Food restriction imposed during the period of liver growth and development increases the mixed-function oxidase system activity, which has a special role in the biotransformation of xenobiotics, such as toxicants, drugs and pollutants (Reen et al., 1999). The association of early protein-calorie malnutrition and acetaminophen administration, at a high dose, could be a reliable approach to study hepatotoxicity protection by a functional food (Walter-Sack, Klotz, 1996; Reen et al., 1999).

The goal of this study was to evaluate the protective effect of turmeric ingestion on body growth and on in vitro lipid peroxidation of hepatocytes from well- and malnourished rats.

\section{MATERIAL AND METHODS}

\section{Chemicals}

Collagenase; pyruvate; Williams medium; epidermal growth factor; $o$-phthalaldehyde (OPT); bovine serum albumin and fetal calf serum were purchased from Sigma Chemical Co. (St. Louis, MO, USA). All other chemicals used were also analytical grade.

Turmeric rhizomes were sliced, blanched, dried in a forced air oven at $60 \pm 2^{\circ} \mathrm{C}$, sieved through a 42 mesh sieve and incorporated into the diet (Bambirra et al., 2002). Acetaminophen was a donation of Minas Gerais State Pharmaceutical Laboratory (FUNED).

\section{Animals}

Pregnant Holtzman rats were randomly distributed into four groups at ca 19 days of pregnancy: 1) WNG (wellnourished group) fed a control diet ad libitum; 2) MNG (malnourished group) fed $60 \%$ of the amount of diet consumed by WNG; 3) WNG+T fed as WNG but the diet contained $1 \%$ of powdered turmeric, and 4) MNG+T fed as MNG but the diet contained $1 \%$ of powdered turmeric. At birth, eight pups per litter, with as many male rats as possible, were used. At weaning ( 21 days of age), the dams were discarded and the male rats were randomly distributed in four groups, housed one animal per cage, and kept at the same diet of the respective mothers. Water was offered ad libitum.

The control diet was prepared using $75 \%$ of a rat lab chow, $25 \%$ of dog food and for each $100 \mathrm{~g}$ of the powder mixture, $100 \mathrm{~mL}$ of a solution containing $4 \%$ commercial gelatin and $1 \%$ cornstarch was added. The formed dough was chopped and dried at $60{ }^{\circ} \mathrm{C}$ in a forced air oven. Experimental diet had the addition of turmeric powder $(1 \%)$ to the control diet, as recommended by Reddy and Lokesh (1994). All control and experimental diets were prepared monthly in the laboratory and stored at $4{ }^{\circ} \mathrm{C}$.

At 90 days of age, the rats were fasted overnight and anesthetized with sodium pentobarbital, $60 \mathrm{mg} / \mathrm{kg}$ body weight (Maslansky, Williams, 1982) before hepatocytes isolation.

\section{Isolation and culture of hepatocytes}

Hepatocytes were isolated by collagenase perfusion according to Seglen (1976), with modifications (Blaauboer et al., 1994). Shortly, the anesthetized rats had the liver exposed and the portal vein perfused with a $\mathrm{Ca}^{2+}$ free solution $(130 \mathrm{mM} \mathrm{NaCl} ; 5.9 \mathrm{mM} \mathrm{KCl} ; 25.0 \mathrm{mM}$ $\mathrm{NaHCO}_{3} ; \quad 1.0 \quad \mathrm{mM} \quad \mathrm{MgSO}_{4} .7 \mathrm{H}_{2} \mathrm{O} ; \quad 1.0 \quad \mathrm{mM}$ $\mathrm{NaH}_{2} \mathrm{PO}_{4} .2 \mathrm{H}_{2} \mathrm{O} ; 5.0 \mathrm{mM}$ glucose; $1.5 \mathrm{mM}$ sodium Llactate; $\mathrm{pH}$ 7.4) for 5 minutes and followed by 3 minutes perfusion with the same medium added $0.1 \mathrm{mM}$ EGTA. The liver was excised and then perfused by circulating the former medium containing $2.1 \mathrm{mg} / \mathrm{mL}$ colagenase; 1.1 $\mathrm{mg} / \mathrm{mL}$ piruvate and $1.7 \mathrm{mg} / \mathrm{mL} \mathrm{CaCl}_{2}$ for 12 to 20 
minutes. The liver was finally immersed in a cold $(0-$ $\left.4^{\circ} \mathrm{C}\right)$ medium $(132 \mathrm{mM} \mathrm{NaCl} ; 5.0 \mathrm{mM}$ glucose; $0.12 \mathrm{mM}$ $\mathrm{CaCl}_{2} ; 0.85 \mathrm{mM} \mathrm{MgCl}_{2} ; 5.2 \mathrm{mM} \mathrm{KCl} ; 15 \mathrm{mM}$ HEPES; 3.0 $\mathrm{mM} \mathrm{NaH} \mathrm{PO}_{4} \cdot \mathrm{H}_{2} \mathrm{O} ; \mathrm{pH}$ 7.4). The Glisson capsule was disrupted, the cells filtered on nylon $(60 \mathrm{~mm})$ and then centrifuged $(0.12 \times g)$ for $30 \mathrm{~s}$ at $4{ }^{\circ} \mathrm{C}$. The last procedure was repeated three times. The whole procedure was undertaken in sterile conditions. More than $85 \%$ viable cells were obtained in this way, as assayed by $0.1 \%$ trypan blue exclusion (Jauregui et al., 1981).

Freshly isolated hepatocytes $\left(3.0 \times 10^{6}\right.$ cells $\left./ \mathrm{mL}\right)$ were pre-incubated at $37{ }^{\circ} \mathrm{C}$ in $3.0 \mathrm{~mL}$ of Williams's medium containing $10 \%$ of fetal calf serum and $0.1 \mathrm{mM}$ insulin in a $5 \% \mathrm{CO}_{2}$ atmosphere. After three hours of incubation the cells were already cemented to the plates and showed a hepatocyte shape. The Williams medium was removed taking along the damaged cells and those that had not adhered to the collagen. The cells were again incubated in Williams medium containing 3\% fetal calf serum; $0.1 \mathrm{mM}$ insulin; $0,1 \mu \mathrm{M}$ dexamethasone; $5.0 \mathrm{nM}$ epidermal growth factor and $1.0 \mathrm{nM}$ glucagon for 24 hours. All incubations were performed in a humidified incubator at $37^{\circ} \mathrm{C}$ and $5 \% \mathrm{CO}_{2}$ (Forma Scientific Inc., Model 3110, USA). At the end of the incubation time, the cells in plates, which were not contaminated, were washed with $1.0 \mathrm{~mL}$ of phosphate-buffered saline and harvested by gently scrapping the plates.

For GSH determination, $350 \mu \mathrm{L}$ of the harvested cells was added to $200 \mu \mathrm{L}$ of $0.5 \mathrm{M} \mathrm{HClO}_{4}$, homogenized, centrifuged at $3.09 \mathrm{x} g$ for $30 \mathrm{~s}$ in a microcentrifuge (FANEN, Mod 242, SP, Brazil) and the supernatant was kept at $-70{ }^{\circ} \mathrm{C}$. Another $500 \mu \mathrm{L}$ aliquote of the harvested cells was added to $300 \mu \mathrm{L}$ of $2 \mathrm{M}$ trichloroacetic acid (TCA) in $1.7 \mathrm{~N} \mathrm{HCl}$, homogenized, centrifuged as above and kept at $-70^{\circ} \mathrm{C}$ for peroxidation index evaluation. Acetaminophen was added to the Williams's medium at the concentrations of 3.0, 6.0 and $12 \mathrm{mM}$ to evaluate its effect on GSH and TBARS content in cultured hepatocytes. The concentration was set after preliminary dose response experiments for GSH content and peroxidation index determinations, but in this case acetaminophen was diluted in dimethyl sufoxide.

The experimental protocol is in accordance to the Ethics Principles for Animal Experimentation of the Ethics Committee for Animal Experimentation of the Universidade Federal de Minas Gerais, Brazil.

\section{Assays}

After harvesting, a volume of $450.0 \mu \mathrm{L}$ of $1.0 \mathrm{~N}$ $\mathrm{NaOH}$ was added to $50.0 \mu \mathrm{L}$ of hepatocytes suspension, heated at $50{ }^{\circ} \mathrm{C}$ for $1 \mathrm{~h}$ and used for protein determination as recommended by Hartree (1972). Bovine serum albumin was used as standard.

Glutathione content was determined according to the method of Hissin and Hilf (1976). Shortly, the sample prepared for this determination was defrosted and a proper volume of a solution made of $1.0 \mathrm{M}$ triethanolamine, $1.65 \mathrm{M}$ $\mathrm{K}_{2} \mathrm{CO}_{3}$ and $30.0 \mathrm{mM}$ EDTA was added to the deproteinized supernatant to adjust the $\mathrm{pH}$ to $6.5-7.0$ and centrifuged at $0.95 \mathrm{x} g$ in the microcentrifuge (FANEN, Mod 242, SP Brazil). To $100 \mu \mathrm{L}$ of this supernatant, $1.8 \mathrm{~mL}$ of phosphateEDTA buffer and $100 \mu \mathrm{L}$ of $o$-phthalaldehyde solution were added. The last solution stood at room temperature for 20 minutes and then the fluorescence read at $350 \mathrm{~nm}$ of excitation and $420 \mathrm{~nm}$ of emission. The results were expressed as mg of GSH per mg of protein.

Lipid peroxidation index was determined according to Bernhein et al. (1948) and Yagi (1984). Two $\mathrm{mL}$ of $1.0 \%$ thiobarbituric acid was added to 500 $\mu \mathrm{L}$ of the sample prepared for this assay. The mixture was incubated in boiling water with agitation for 30 minutes. After cooling, the color was read at $535 \mathrm{~nm}$ (Hitachi spectrophotometer Mod U-2001, Japan). The results were converted in nmol of TBARS per mg of protein, using the molar extinction coefficient for malonaldehyde.

\section{Statistical analysis}

The results are mean \pm SEM of four rats from each experimental group. Data obtained were subjected to ANOVA analysis and the significant differences in the experimental values were determined using the Duncan test. Values were considered statistically different at $\mathrm{P}<0.05$.

\section{RESULTS}

Table I shows the results of $1 \%$ turmeric ingestion on body weight of weaning ( 21 days of age) and adult ( 90 days of age) well-nourished and malnourished rats. No effect of turmeric ingestion was observed in body weight gain of well-nourished or malnourished rats. Food restriction (40\%) since birth, however, decreased rat's body weight at weaning $(55 \%)$ and at the sacrifice (33\%).

At optical microscopy, the cells monolayer of the cultured hepatocytes were normally aggregated in the controls while they were dispersed in the plates treated with acetaminophen, except when the animals were fed diet supplemented with turmeric (data not shown). Doseresponse curve (Figure 1) showed the toxic effect exerted by the presence of acetaminophen in the culture medium. In 
TABLE I - Effect of turmeric ingestion on body weight of well-nourished and malnourished rats

\begin{tabular}{lcccc}
\hline Age (days) & \multicolumn{4}{c}{ Body weight $(\mathrm{g})$} \\
\hline & WNG & WNG+T & MNG & MNG+T \\
21 & $43.4 \pm 2.1$ & $47.1 \pm 1.9$ & $19.6 \pm 0.2$ & $19.8 \pm 0.3$ \\
90 & $344.9 \pm 7.5$ & $344.0 \pm 7.0$ & $230.1 \pm 4.7$ & $234.3 \pm 6.2$ \\
\hline
\end{tabular}

WNG: well-nourished group fed ad libitum; MNG: malnourished group that received $60 \%$ of food consumed by the WNG group, $\mathrm{WNG}+\mathrm{T}$ and $\mathrm{MNG}+\mathrm{T}$ indicate the well-nourished and malnourished groups that received diet with $1 \%$ turmeric. The results are expressed as mean \pm standard error. Body weight of malnourished rats was lower at both ages $(\mathrm{P}<0.05)$.

both well-nourished and malnourished rats, an increase in TBARS content, respectively of $50 \%$ and $54 \%$, was detected at the concentration of $6 \mathrm{mM}$ in the culture medium. Toxic effect of acetaminophen at the concentration of $6 \mathrm{mM}$ in the culture medium was attested to by the decrease of GSH content, c.a. $61 \%$ in well-nourished and c.a. $63 \%$ in malnourished rats (Figure 2). Dose response curve also shows an increase in GSH content by malnutrition, in the absence or in the presence of $3 \mathrm{mM}$ acetaminophen in the culture medium. This difference was abolished at $6 \mathrm{mM}$ acetaminophen in the medium.

Table II shows results of the effect of turmeric ingestion on membrane lipid peroxidation of hepatocytes primary culture from well-nourished and malnourished rats. In the absence of acetaminophen, turmeric ingestion decreased the content of TBARS in cells from wellnourished (42\%) and from malnourished $(33 \%)$ rats. In the presence of $6 \mathrm{mM}$ acetaminophen, TBARS content also decreased in cells from well-nourished (40\%) and from malnourished (38\%) rats. Food restriction also decreased the content of TBARS in cells not treated (42\%) or treated with acetaminophen (33\%). On the other hand, in wellnourished rats acetaminophen increased TBARS content in hepatocytes from animals fed turmeric (38\%) or not $(33 \%)$. However, in the acetaminophen treated cells from wellnourished animals fed turmeric, the increase in TBARS content was lesser $(19 \%)$ when compared with cells from animals fed diet without turmeric and not treated with acetaminophen (well-nourished control cells). In malnourished rats, acetaminophen increased TBARS content in animals fed turmeric $(43 \%)$ or not $(52 \%)$. However, the values found in cells from malnourished rats fed turmeric and challenged with acetaminophen were similar to those found in not challenged cells from malnourished animals without turmeric ingestion (malnourished control).

\section{DISCUSSION}

In the present study it was observed that protein and calorie restriction, imposed to rats early in life, reduced lipid peroxidation index and increased the content of GSH. This is in accordance with in vitro studies demonstrating that malnutrition decreases cell damage caused by free radicals (Masoro, 1989).

The small number of experimental animals allowed us to utilize hepatocyte primary cultures which reproduce the hepatic functions in many aspects, as usual in studies of biotransformation, cytotoxicity and genotoxicity of xenobiotics (Maslansky, Williams, 1982). The functional and structural complexities of the intact cells were maintained, favoring experimental results extrapolations and the accomplishment of the proposed objectives.

Biological protection afforded by several plants depends on the presence of components with antioxidant activity, as is the case of Curcuma longa (Ramsewak et $a l ., 2000)$. One percent of turmeric in the diet was

TABLE II - Effect of turmeric ingestion on lipid membranes peroxidation of hepatocytes primary culture treated with acetaminophen from well-nourished and malnourished rats

\begin{tabular}{|c|c|c|c|c|}
\hline Acetaminophen & WNG & $\mathrm{WNG}+\mathrm{T}$ & MNG & $\mathrm{MNG}+\mathrm{T}$ \\
\hline$(\mathrm{mM})$ & \multicolumn{4}{|c|}{ (nmol TBARS/ mg protein) } \\
\hline 0 & $0.036 \pm 0.001^{b}$ & $0.021 \pm 0,001^{\mathrm{d}}$ & $0.021 \pm 0.001^{\mathrm{d}}$ & $0.014 \pm 0.001$ \\
\hline 6 & $0.048 \pm 0.002^{\mathrm{a}}$ & $0.029 \pm 0.001^{\mathrm{c}}$ & $0.032 \pm 0.001^{\mathrm{c}}$ & $0.020 \pm 0.001^{\mathrm{d}}$ \\
\hline
\end{tabular}

The results are expressed as mean \pm standard error $(n=4)$. Different superscript letters indicate statistical differences $(\mathrm{P}<0,05)$. WNG stands for well-nourished group; MNG stands for malnourished group; WNG+T and MNG+T stand for well-nourished and malnourished groups supplemented with $1 \%$ turmeric. 
recommended by Reddy and Lokesh (1994) to obtain cellular protective effects. It was observed here that turmeric does not affect body weight gain or food ingestion in rats, which is in accordance with the literature (Goud et al., 1993). Turmeric, however, presented significant antioxidant activity, confirming data from Donatus et al. (1990), the inhibition of lipid peroxidation probably being due to arrest of oxygen reactive species (Antunes, Araújo, 2000).

On the other hand, it was interesting to examine the protective effect of turmeric on cells challenged by the presence of acetaminophen a well known hepatotoxic compound. Hepatocytes primary culture is adequate to study the effect of acetaminophen hepatotoxicity (Jochemsen et al., 1993). The doseresponse curves (Figures 1 and 2) related to lipid peroxidation and GSH content showed that $6 \mathrm{mM}$ acetaminophen was found to be able to cause in vitro toxic effects of the drug. The mechanism of the hepatotoxic protection of turmeric, as a functional food, is not entirely elucidated, but it is possible that the inhibition of lipid peroxidation contributes to the

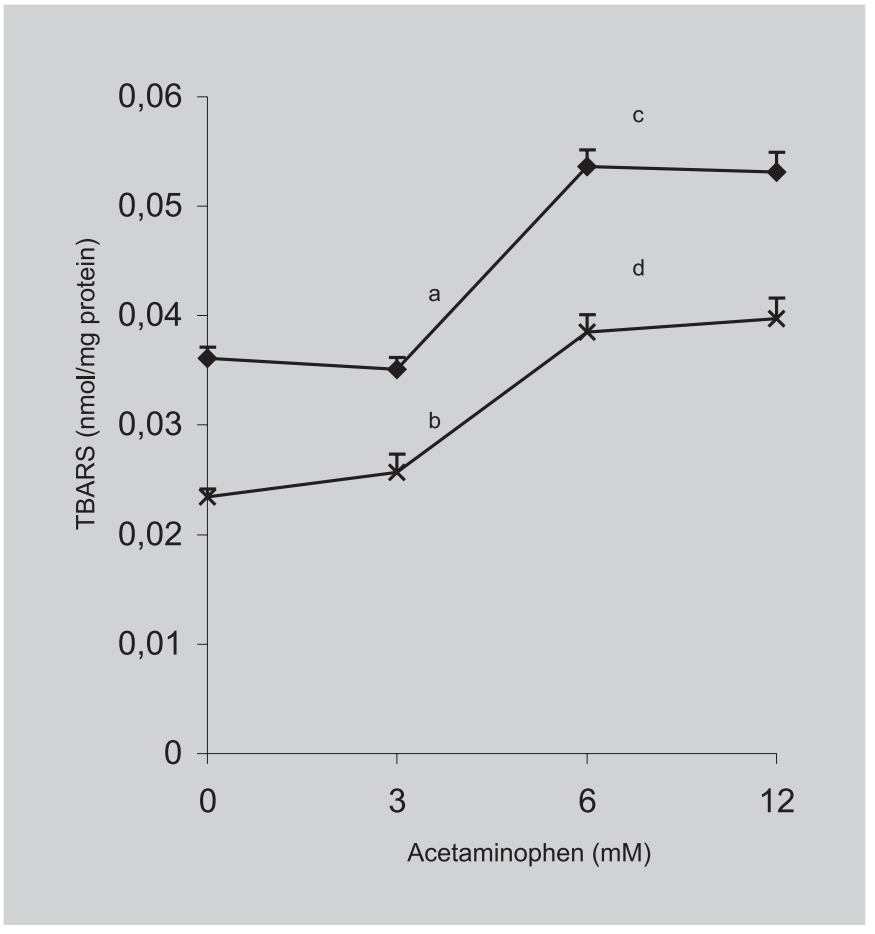

FIGURE 1 - Dose response curve of the effect of acetaminophen on lipid membrane peroxidation of hepatocytes primary culture expressed as thiobarbituric acid reactive substances (TBARS) from well-nourished $(\diamond)$ and malnourished $(\times)$ rats. The results are expressed as mean \pm standard error $(n=4)$. Different letters indicate statistical differences $(\mathrm{P}<0.05)$.

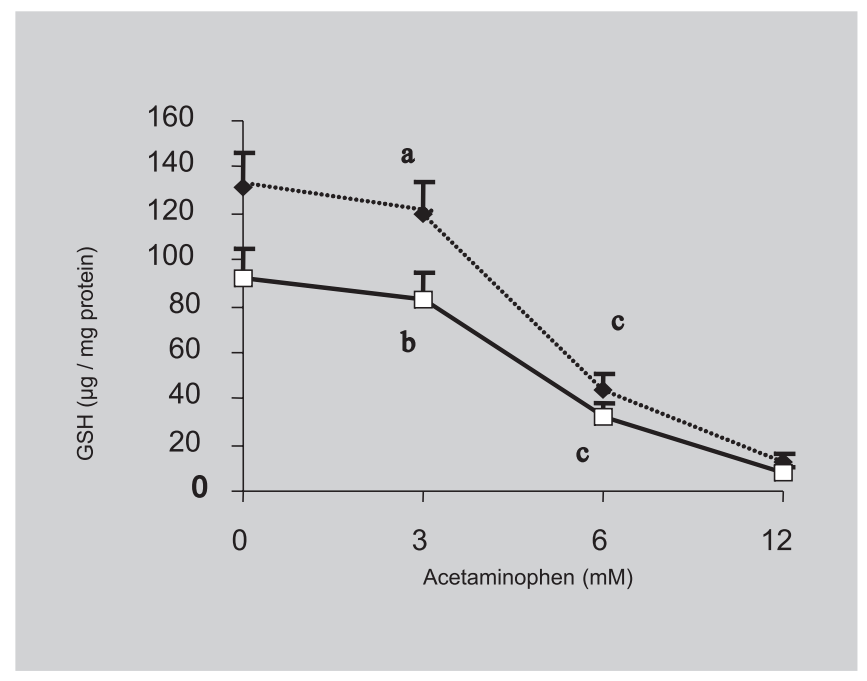

FIGURE 2 - Dose response curve of the effect of acetaminophen on the content of GSH in hepatocytes primary culture from well-nourished $(\square)$ and malnourished $(\diamond)$ rats. The results are expressed as mean \pm standard error $(n=4)$. Different letters indicate statistical differences $(\mathrm{P}<0.05)$.

protection against toxic effects caused by high dose of acetaminophen regardless their nutritional status.

\section{CONCLUSION}

The functional food, known as turmeric, is able to minimize hepatotoxicity caused by the presence of high concentration of acetaminophen in hepatocyte primary culture, which was followed by membrane peroxidation in cells from normal and food restricted rats. Toxicity of acetaminophen was estimated by dose-response curves related GSH decrements and increased TBARS content in hepatocytes cultures from well-nourished and malnourished rats.

\section{RESUMO}

\section{Ingestão de Curcuma longa protege contra peroxidação de membrana de hepatócito}

O objetivo do presente estudo foi avaliar o efeito da ingestão de cúrcuma sobre a peroxidação lipídica e conteúdo de GSH, por ação tóxica in vitro de paracetamol, utilizando cultura primária de hepatócitos. Quatro grupos de ratos Holtzman foram usados: 1) GNN, normonutrido, alimentado ad libitum com ração de laboratório; 2) GDN, desnutrido, alimentado com $60 \%$ da quantidade de ração consumida por $G N N$; 3) $G N N+C$, alimentado como GNN, mas conten- 
do $1 \%$ de cúrcuma na dieta; 4) $G D N+C$, alimentado como GDN, mas contendo $1 \%$ de cúrcuma na dieta. Os animais foram sacrificados aos 90 dias de vida, e cultura de hepatócitos preparada. Metade das placas de cultura foi tratada com paracetamol. A curva dose-resposta mostrou que $6 \mathrm{mM}$ de paracetamol aumentou em $54 \%$ a peroxidação e diminuiu em $63 \%$ o conteúdo de GSH. A restrição na ingestão de alimentos (40\%) diminuiu o peso corporal (33\%) ao sacrifício e o indice de peroxidação cerca de $42 \%$, entretanto, aumentou o conteúdo de GSH cerca de 43\%. A ingestão de cúrcuma diminuiu a peroxidação em ambos ratos normonutridos (42\%) e desnutridos (33\%) e evitou o efeito prooxidante de paracetamol em ambos os grupos. A cúrcuma exerceu efeito protetor antioxidante sobre o organismo.

UNITERMOS: Cúrcuma. Paracetamol. Restrição alimentar. Peroxidação de lipídeos. Cultura primária de hepatócitos.

\section{ACKNOWLEDGMENT}

The authors are indebted to Dr. Maria Beatriz Abreu Glória for helping in the preparation of the manuscript and to the Fundação de Amparo à Pesquisa do Estado de Minas Gerais (FAPEMIG) and the Conselho Nacional de Desenvolvimento Científico e Tecnológico (CNPq) for financial support.

\section{REFERENCES}

ANTUNES, L.M.G.; ARAÚJO, M.C.P. Mutagenicidade e antimutagenicidade dos principais corantes para alimentos. Rev. Nutr., v. 13, p. 81-88, 2000.

BAMBIRRA, M.L.A.; JUNQUEIRA, R.G.; GLORIA, M.B.A. Influence of post harvest processing conditions on yield and quality of ground turmeric (Curcuma longa L.). Braz. Arch. Biol. Technol., v. 45, n. 4, p. 423-429, 2002.

BERNHEIN, F.; BERNHEIN, M.L.C.; WILBUR, K.M. The reaction between thiobarbituric acid and the oxidation products of certain lipids. J. Biol. Chem., v.174, p. 257264, 1948.

BESSEMS, J.G.M.; VERMEULEN, N.P.E. Paracetamol (acetaminophen)-induced toxicity: molecular and biochemical mechanisms, analogues and protective approaches. Crit. Rev. Toxicol., v. 31, p. 55-138, 2001.
BLAAUBOER, B.J.; BOOBIS, A.R.; CASTELL, J.V. The practical applicability of hepatocyte culture in routine testing. Atla, v. 22, p. 231-241, 1994.

DONATUS, I.A.; SARDJOKO; VERMEULEN, N.P.E. Cytotoxic and cytoprotective activities of curcumin Effects on acetaminophen-induced cytotoxicity, lipid peroxidation and glutathione depletion in rat hepatocytes. Biochem. Pharmacol., v. 39, n. 12, p. 1869-1875, 1990.

GOUD, V.K.; POLASA, K.; KRISHNASWAMY, K. Effect of turmeric on xenobiotic metabolising enzymes. Plant Foods Human Nutr., v. 44, p. 87-92, 1993.

HARTREE, E.F. Determination of protein: a modification of the Lowry method that gives a linear photometric response. Anal Biochem., v. 48, p. 422-427, 1972.

HISSIN, P.J.; HILF, R. A fluorimetric method for determination of oxidized and reduced glutathione in tissue. Anal. Biochem., v. 74, p. 214-226, 1976.

IQBAL, M.; SHARMA, S.D.; OKASAKI, Y.; FUJISAWA, M.; OKADA, S. Dietary supplementation of curcumin enhances antioxidant and phase II metabolizing enzymes in ddY male mice: possible role in protection against chemical carcinogenesis and toxicity. Pharmacol. Toxicol., v. 92, n. 1, p. 33-38, 2003.

JAUREGUI, H.O.; HAYNER, N.T.; DRISCOLL, J.L.; WILLIAMS-HOLLAND，R.; LIPSKY，M.H.; GALLETTI, P.M. Trypan Blue dye uptake and lactate dehydrogenase in adult rat hepatocytes-freshly isolated cells, cells suspensions, and primary monolayer cultures. In Vitro, v. 17, p. 1100-1110, 1981.

JOCHEMSEN, R.; BAZOT, D.; BRILLANCEAU, M.H.; LUPART, M. Assessment of drug exposure in rat dietary studies. Xenobiotica, v. 23, p. 1145-1154, 1993.

JOE, B.; VIJAYKUMAR, M.; LOKESH, B.R. Biological properties of curcumin-cellular and molecular mechanisms of action. Crit. Rev. Food Sci. Nutr., v. 44, n. 2, p. 97-111, 2004.

KAWAMORI, T.; LUBET, R.; STEELE, V.E.; KELLOFF, G.J.; KASKEY, R.B.; RAO, C.V.; REDDY, B.S. Chemopreventive effect of curcumin, a naturally occurring anti-inflammatory agent, during the promotion/progression stages of colon cancer. Cancer Res., v. 59, p. 597-601, 1999. 
KISO, J.; SUZUKI, Y.; WATANABE, A.; OSHIMA, Y.; HIKIHO, H. Anti-hepatotoxic principles of Curcuma longa rhizomes. Plant Res. Med., v. 49, p. 184-187, 1983.

MASLANSKY, C.J.; WILLIAMS, GM. Primary cultures and levels of cytochrome $\mathrm{P} 450$ in hepatocytes from mouse, rat, hamster, and rabbit liver. In Vitro, v. 18, p. 683- 693, 1982.

MASORO, E.J. Mini review: Food restriction in rodents: an evaluation of its role in the study of aging. J. Gerontol. Biol. Sci., v.43, n. 3, p. 59-64, 1989.

MASUDA, T.; JTOE,A.Antioxidative and anti-inflammatory compounds from tropical gingers: Isolation, structure determination, and activities of Cassumunins $\mathrm{A}, \mathrm{B}$ and $\mathrm{C}$, new complex curcuminoids from Zingiber cassumunar.J. Agric. Food Chem., v. 42, p. 850-1856, 1994.

PLAA, G.L.; WITSCHI, H. Chemicals, drugs and lipid peroxidation. Ann. Rev. Pharm. Toxicol., v. 1, p. 125-141, 1976.

POLI, G.; ALBANO, E.; DIANZANI, M.U. The role of lipid peroxidation in liver damage. Chem. Phys. Lipids, v. 45, p. $117-142,1987$.

PRESCOTT, L.F. Paracetamol overdosage. Drugs, v. 25, p. $290-314,1983$.

RAMPRASAD, C.; SIRSI, M. Observations on the pharmacology of Curcuma longa. Studies in Indian plants Curcuma longa Linn. - Effects of curcumin and essential oil of C. longa on bile secretion. J. Sci. Res. Inst., v. 15, p. 212-216, 1956.

RAMSEWAK, R.S.; DEWITT, D.L.; NAIR, M.G. Cytotoxicity, antioxidant and anti-inflammatory activities of curcumins I-III from Curcuma longa. Phytomed., v. 7, n. 4, p. 303-308, 2000.
REDDY, A.C.P.; LOKESH, B.R. Effect of dietary turmeric (Curcuma longa) on iron-induced lipid peroxidation in the rat liver. Food Chem. Toxicol., v. 32, p. 279-283, 1994.

REEN, R.K.; MELO, G.E.B.A.; MORAES-SANTOS, T. Malnutrition sequela on the drug metabolizing enzymes in male Holtzman rats. J. Nutr. Biochem., v. 10, p. 615 $618,1999$.

SEGLEN, P.O. Preparation of isolated rat liver cells. Methods Cell Biol., v. 13, p. 29-83, 1976.

SERGENT, O.; MOREL, I.; COGREL, P.; CHEVANNE, M.; PASDELOUP, N.; BRISSOT, P.; LESCOAT, G.; CILLARD, P.; CILLARD, J. Simultaneous measurements of conjugated dienes and free malondialdehyde, used as a micromethod for the evaluation of lipid peroxidation in rat hepatocyte cultures. Chem. Phys. Lipids, v. 65, p. 133-139, 1993.

VERMEULEN, N.P.E.; BESSEMS, J.G.M.; VAN DE STRAAT, R. Molecular aspects of paracetamol-induced hepatotoxicity and its mechanism-based prevention. Drug Metab. Rev., v. 24, n. 3, p. 367-407, 1992.

WALTER-SACK, I.; KLOTZ, U. Influence of diet and nutritional status on drug metabolism. Clin. Pharmacol., v. 31, p. 47-64, 1996.

YAGI, K. Assay for blood plasma and serum. Methods Enzymol., v. 105, p. 328-341, 1984.

Recebido para publicação em 11 de junho de 2005. Aceito para publicação em 03 de fevereiro de 2006. 